\title{
A Noiseless Crime Contributing to the Violation of Women Rights: Domestic Violence a Continuous nightmare on Women Rights and Status. The Need for Extermination or Continuation in Cameroon?
}

\author{
Nana Charles Nguindip $^{1 *}$, Ngemuah Nongde ${ }^{2}$
}

${ }^{1}$ Senior Lecturer in Law, Faculty of Laws and Political Science, Departmnet of English Law, University of Dschang P.O Box 96 Dschang, Cameroon

${ }^{2}$ Assistant Lecturer, Faculty of Law and Political Science, Department of English Law, University of Yaounde II Soa, Cameroon

\begin{abstract}
DOI: $10.36348 /$ sijlcj.2021.v04i02.006
| Received: 22.01.2021 | Accepted: 08.02.2021 | Published: 13.02.2021
\end{abstract}

*Corresponding author: Nana Charles Nguindip

\section{Abstract}

Women violence is a deeply rooted problem that exists in every country of the globe. For the most part; nevertheless, the international community has yet to create operational legal standards that will exclusively address the problems and intricacies experienced by women via domestic violence. Notwithstanding this unfortunate emptiness, the rights of battered women may be asserted under international and regional Human Rights Conventions that are legally binding upon ratifying States. This article articulates that the cankerworm of domestic violence though hypocritically and pretentiously combatted by the government of Cameroon through its various legal dispositions, has still, and continues to be considered by many as a silent or noiseless crime affecting the status of women. Women in the generic sense of the word, continue to be victims of domestic violence. This state of affairs has evidently posed negative implications on their various rights and integrity. The government of Cameroon has failed in respecting the international prescription and commitments in respecting the fundamental rights of women as their violation and abuses continue to be on the rise.

Keywords: Noiseless Crime, Violations Women Rights, Domestic Violence, Women Rights, Extermination, Continuation.

Copyright (C) 2021 The Author(s): This is an open-access article distributed under the terms of the Creative Commons Attribution 4.0 International License (CC BY-NC 4.0) which permits unrestricted use, distribution, and reproduction in any medium for non-commercial use provided the original author and source are credited.

\section{INTRODUCTION}

Domestic violence in Cameroon is a pervasive problem. A 2016 study found that, of 2,570 women, $995(38.7 \%)$ reported physical violence and 381 (14.8\%) reported sexual violence [1]. These data match more recent statistics, including a study from Doualabased La Maison des Droits de l'Homme that approximately 39 percent of Cameroonian women suffered from physical violence in 2008 [2]. These numbers indicate that little has been done to stem the epidemic of domestic violence in Cameroon in recent

\footnotetext{
${ }^{1}$ Alio, Amina P. "Association between intimate partner violence and induced abortion in Cameroon," 112 International Journal of Gynecology \& Obstetrics 2 (Feb. 2011).

${ }^{2}$ NGO Report On the implementation of the ICCPR (Replies to the List of Issues, available at CCPR/C/CMR/Q4)http://www2.ohchr.org/english/bodi es/hrc/docs/ngos/GeED_Cameroon_HRC99.pdf (last visited August 20, 2020
}

years. The vast majority of victims are female: $92 \%$ of domestic violence victims in Cameroon are women. Cameroon's Penal Code does not specifically criminalize domestic violence. Victims are thus left to rely on the general assault provisions in the Penal Code, which address murder (Articles 275 and 276), grievous harm (Article 277), assault causing death (Article 278), assault causing grievous harm (Article 279), simple harm (Article 280), failure to assist women abandoned by their husbands (Article 282), and assault of a pregnant woman (Article 338) [3]. In its National Report, the Cameroon Government asserts that domestic violence and spousal abuse will be "better expressed in the penal code currently under revision" and in the meantime, such crimes can be punished

\footnotetext{
3 Immigration and Refugee Board of Canada, Cameroon: Domestic violence, including legislation, availability of state protection and support services for victims, 2 December 2010, CMR103371, available at: http://www.refworld.org/docid/4db7b9d92.html (last accessed 23 August 2013).
} 
through "various classifications of injuries" under the existing legal framework described above. But the process to prosecute these "injuries" under the current code is anything but clear in the context of domestic abuse. Cameroon asserted in its National Report that: "... with regard to punishment for spousal rape, 'any man who uses physical or moral violence to have sexual relations with a woman shall be punished by imprisonment for a term of five to 10 years $\left[{ }^{4}\right]$ '. However, the United States State Department and reputable Human Rights Organizations refute that statement, arguing that Article 296 of the Penal Code does not apply to spousal rape. In its National Report, Cameroon also indicated that: "A husband who uses violence to force his wife to have sexual relations with him may be prosecuted for causing intentional injury, depending on the severity of the violence; all of this is a question of fact left to the discretion of the judge hearing the case of the victimized wife." Further, rather than focusing on the lack of consent, criminal justice hinges on the presence of injury which may not be visible, present, documented, or difficult to prove. Based on these (potentially conflicting) statements, it is unclear as to what exactly the legal system provides in terms of enforcement against spousal rape and, more generally, domestic violence.

\section{The Need for addressing aspects of Violence against Women in Cameroonian Laws}

Victims of domestic abuse in Cameroon have little recourse for protection. There is no domestic violence law in Cameroon that provides women with an order for protection against abusers. The Family Code that was drafted in 1997 to address issues of domestic violence, has remained on the shelf, unadopted and unimplemented. Stakeholders see this failure to adopt the law as a lack of political will to address domestic violence. Women seeking to escape the violence through divorce are further hindered by the fact that spousal abuse is not a legal ground for divorce [5].

The issue of domestic violence has been a great preoccupation to the Cameroon government. They believe that the problem we have nowadays is not just to be a party of a treaty, convention, covenant or declaration. In showing its commitment and engagement in respective human right laws, the country saw the need to ratified necessary laws dealing with women treatment. In 2012, Cameroon ratified the Protocol to the African Charter on Human and Peoples' Rights on the Rights of Women in Africa (The Maputo Protocol). It is really surprising that ever since Cameroon ratified this Protocol, there country till this moment has done nothing in establishing or enacting a

\footnotetext{
${ }^{4}$ article 296 of the Penal Code.

${ }^{5}$ Country Reports on Human Rights Practices for 2012: Cameroon, U.S. Department of State (2012), at 27.
}

law or bill that comprehensively addresses violence against women, however a draft law addressing violence against women and gender-based discrimination is under consideration. The country has however enacted some laws pertaining to different forms of violence against women, such as rape, sexual harassment, and female genital mutilation. In 2012, the government drafted a National Strategy to Combat Violence against Women, provided health and financial assistance victims, established and operate a hotline for victim support and reporting cases, and implemented awareness-raising activities at the national and local levels.

\section{The Cameroon Legal Nomenclature in the Domain of Female Violence and Discrimination}

The State of Cameroon assures its citizens equality and non-discrimination in its Constitution which includes and incorporates the Universal Declaration of Human Rights. Article 1(2) "ensures the equality of all citizens before the law." The Preamble recognizes the Government's obligation to "protect women and the young" and guarantees to each individual "freedom and security." The Constitution's Preamble affirms Cameroon's “attachment to the fundamental freedoms enshrined in the Universal Declaration of Human Rights, the Charter of the United Nations and the African Charter on Human and Peoples' Rights, and all duly ratified international conventions relating thereto." Article 45 of the Constitution emphasizes Cameroon's membership in the international community, recognizing that "duly approved and ratified treaties and international agreements shall ... override national laws." Cameroon ratified the Protocol to the African Charter on Human and Peoples' Rights on the Rights of Women in Africa (the so-called Maputo Protocol) in 2012 [6].

The Constitution of the Republic of Cameroon (1996), as amended in 2008, does not explicitly refer to violence against women, harmful practices or FGM. The Preamble states, however, that 'every person has a right to life, to physical and moral integrity and to humane treatment in all circumstances. Under no circumstances shall any person be subjected to torture, to cruel, inhumane or degrading treatment [7]'. There is no national legislation in Cameroon, comprehensively addressing violence against women. However, the country has passed some laws addressing different forms of violence against women, such as rape, sexual harassment, and genital mutilation. In 2012, the

\footnotetext{
${ }^{6}$ ACHPR, Protocol to the African Charter on Human and Peoples' Rights on the Rights of Women in Africa Legal Instruments, 11 July 2003

${ }^{7}$ Cameroon, Constitution of the Republic of Cameroon Law No. 96-06 of 18 January 1996 to amend the Constitution of 2 June 1972
} 
government drafted a National Strategy to Combat Violence against Women, established a hotline for victim support and reporting cases, and implemented awareness-raising activities at the national and local levels [8]. In practice, violence against women is highly prevalent throughout the country, in large part due to lack of adequate legislation and systematic action to eradicate stereotypes and harmful practices against women.

\section{An Increasing Violation and Continuous Depicting and Smashing Abuses on the Women Status}

Notwithstanding government efforts in issues relating to combating domestic violence, there is a high prevalence of violence against women throughout the country, in large part due to the inadequate legislation to address the problem and lack of systematic action to eliminate stereotypes and harmful practices that discriminate against women $\left[{ }^{9}\right]$. Paired with this is a limited number of investigations and prosecutions of such cases and overall failure to hold perpetrators accountable. Domestic violence in Cameroon is a pervasive problem. A 2018 study found that, of 2,570 women, $995(38.7 \%)$ reported physical violence and $381(14.8 \%)$ reported sexual violence [10]. These data match more recent statistics, including a study from Douala-based La Maison des Droits de l'Homme that approximately 39 percent of women suffered from physical violence in 2008 [11], thus indicating that little has been done to stem the epidemic of domestic violence over the years. The vast majority of victims are women, as females account for $92 \%$ of domestic violence victims in Cameroon [12]. The Government of Cameroon fails to engage in effective criminal investigation and prosecution of domestic violence acts. Cameroon's penal code does not specifically criminalize domestic violence [13]. In the absence of a

\footnotetext{
${ }^{8}$ OECD Social Institutions and Gender Index, Country Profile: Cameroon, 2019

${ }^{9}$ CEDAW, 2014; UNECA, 2014; Advocates of Human Rights, 2014

10 Alio, Amina P. "Association between intimate partner violence and induced abortion in Cameroon," 112 International Journal of Gynecology \& Obstetrics 2 (Feb. 2018)
}

11 159NGO Report On the implementation of the ICCPR (Replies to the List of Issues, available at CCPR/C/CMR/Q4)http://www2.ohchr.org/english/bodi es/hrc/docs/ngos/GeED_Cameroon_HRC99.pdf (last visited August 20, 2013).

${ }^{12}$ L'Association Camerounaise des Femmes Juristes, Lutte contre les violences faites aux femmes au Cameroun: Une mobilisation Considérable, Justice \& Solidarité, July 2012, p. 4.

${ }^{13}$ Country Reports on Human Rights Practices for 2012: Cameroon, U.S. Department of State (2012), at 27; Beijing +15 , "The Stance of Cameroon and the specific criminal domestic violence provision, victims are thus left to rely on the general assault provisions in the Penal Code, which address murder (Articles 275, 276), grievous harm (Article 277), assault causing death (Article 278), assault causing grievous harm (Article 279), simple harm (Article 280), failure to assist women abandoned by their husbands (Article 282), and assault of a pregnant woman (Article 338) [14]. Marital rape is not a crime under Cameroon law [15]. Current attempts at legal reform do not suggest that prohibiting marital rape is a priority objective of the Government of Cameroon at this time. The Government of Cameroon's 3rd Periodic Report states that "the draft bill of the Criminal Code, which is in the process of being finalized, contains provisions that criminalize violence against women, in particular sexual harassment, disruption of growth of an organ etc [16]." This paragraph does not include, however, any specific mention of criminalizing spousal rape.

Although general assault and murder provisions are available, legal systems actors' practices show a failure to prioritize the prosecution of domestic violence. Domestic violence is generally considered a private matter by the community and law enforcement and is rarely addressed at the level of the courts for these same reasons [ 17 ]. Harmful practices also perpetuate domestic violence, as men at times defend their use of domestic violence because of the bride price they paid for their wives [18]. In its 3rd Periodic Report, the Government of Cameroon points out the 2010 indictment of one defendant, a police officer, for

Unfinished Business," Gender Power and Development, July 2010, pg. 36 .

14 Immigration and Refugee Board of Canada, Cameroon: Domestic violence, including legislation, availability of state protection and support services for victims, 2 December 2010, CMR103371, available at: http://www.refworld.org/docid/4db7b9d92.html].

15 Country Reports on Human Rights Practices for 2012: Cameroon, U.S. Department of State (2012), at 27.

16 3rd Government Report within the Framework of the African Charter on Human and Peoples' Rights, Section 30.

${ }^{17}$ Beijing +15 , "The Stance of Cameroon and the Unfinished Business," Gender Power and Development, July 2010, pg. 35-36.

${ }^{18}$ Johnson Takwa, Teke. 2009. "Violence Against the Women and the Girl Children in Cameroon." Poster presented at the International Conference on Population, 27 September-2 October 2009, Marrakech, Morocco, at 5, http://iussp2009.princeton.edu/papers/90344. 
murdering his wife, a magistrate [19]. While the prosecution of this single offender for domestic violence homicide is a welcome step toward offender accountability, the Report makes no other reference to or mention of prosecution for the hundreds of other domestic violence cases in Cameroon. Moreover, victims of domestic abuse have little recourse for protection. There is no domestic violence law in Cameroon that would provide women with an order for protection against their abusers [20]. The Family Code that was drafted in 1997 to address issues of domestic violence has remained on the shelf [21]. Stakeholders see this failure to adopt the law as a lack of political will to address domestic violence [22]. Women seeking to escape the violence through divorce are hindered by the fact that spousal abuse is not a legal ground for divorce [23]. Other practices by the government also create additional obstacles for victims seeking safety. The Cameroonian Government in its report states that it provides marital and family mediation services in cases of marital or family disputes, noting that its counselling and mediation units processed 17,000 cases and settled 3,668 of them "amicably [24]." It is well-documented; however, that mediation is problematic and dangerous for domestic violence victims, because the assumptions underlying the use of mediation do not apply when there has been domestic violence. Mediation assumes that both parties are equal, yet an abuser holds tremendous power over a victim. This imbalance of power between the parties cannot be remedied, even with the skills of a trained mediator. During mediation, the abuser can easily control the victim through the use of signals known only to the couple. Also, a victim is often afraid and reluctant to voice her concerns. Further, mediation focuses on future behaviour, and many mediators do not allow the victim to address past issues of violence. This furthers the victim's sense of personal responsibility for the abuse, and undermines the accountability of the abuser [25].

${ }^{19}$ 3rd Government Report within the Framework of the African Charter on Human and Peoples' Rights, para. 505

${ }^{20}$ Nisha Giridhar, The Global Spread of Domestic Violence Legislation: Causes and Effects (Spring 2012), at 20, http://politics.as.nyu.edu/docs/IO/4600/Giridhar_Nisha. pdf.

${ }^{21}$ Written Communication with Ndi Richard Tanto, Ecumenical Service for Peace, Aug. 20, 2013.

${ }^{22}$ Ibid.

${ }^{23}$ Country Reports on Human Rights Practices for 2012: Cameroon, U.S. Department of State (2012), at 27

${ }^{24} 3$ rd Government Report within the Framework of the African Charter on Human and Peoples' Rights, paras, $446,506$.

25 Mediation, StopVAW, Feb. 2008, http://www.stopvaw.org/Mediation

\section{A factual and practicable act violating Female} Rights in Cameroon

More than a half of women $(55 \%)$, since the age of 15 , have been physically abused, mainly by their husband or partner $\left[{ }^{26}\right]$. While it is true that the current husband / partner (51\%) remains the principal perpetrator of physical violence, the most recent husband / partner (16\%), father's mother or wife $(15 \%$ or the husband of the mother $(14 \%)$ and the sister or brother $(12 \%)$, teachers $(8 \%)$ are the other perpetrators of physical violence against women $\left[{ }^{27}\right]$; Of the women who have had sexual intercourse, $20 \%$ were forced to have first sexual intercourse and $30 \%$ had sexual intercourse before the age of $15\left[{ }^{28}\right]$; Overall, $41 \%$ of women reported that they were aged 15 to 49 at the time when they first experienced sexual abuse and $19 \%$ were 10 to 14 years old at the time of the experiment $\left[{ }^{29}\right]$. Overall, $34 \%$ of women between the ages of 15 and 49 were physically assaulted, only $8 \%$ were sexual assaults, and $21 \%$ were both physical and sexual $\left[{ }^{30}\right]$; among pregnant women, $14 \%$ of women reported experiencing violence during pregnancy; among women in union or in a break-up, a total of $60 \%$ of women have experienced physical, sexual and / or emotional violence by their current or most recent husband $\left[{ }^{31}\right]$. According to the National Institute Statistics in 2016 [ $\left.{ }^{32}\right]$ in the last 12 months prior to the survey, $29 \%$ of women have been physically abused; almost two out of three women reported being physically abused at any time. $11 \%$ of women were victims of sexual violence and $33 \%$ of emotional violence. Among women in union, $40 \%$ said they had injuries. The occurrence of injuries as a result of acts of physical or sexual violence is $43 \%\left[{ }^{33}\right]$.

\section{Rationalising and Criminalizing this Salient Crime in Cameroon}

Violence on women is not recognised as a specific crime in Cameroon and we don't have a legal definition of domestic violence. Cameroon does not have specific legislation by which domestic violence can be prosecuted; the criminal law is notoriously silent and victims are left to rely on the general law of assault.

\footnotetext{
26 Institut National de la Statistique (INS) et ICF International, Enquête Démographique et de Santé et à Indicateurs Multiples, Calverton, Maryland, USA, INS et ICF International, septembre 2012, pp. 327-328.

${ }^{27}$ Ibid., p. 329 .

${ }^{28}$ Ibid., p. 333

${ }^{29}$ Ibid., p.330.

${ }^{30}$ Ibid., p.334.

${ }^{31}$ Ibid., p.337

32 Institut National de la Statistique (INS) et ICF International, Enquête Démographique et de Santé et à Indicateurs Multiples, Calverton, Maryland, USA, INS et ICF International, septembre 2016, pp. 327-328.
} 
Thus, acts of domestic violence can be prosecuted using the Cameroon's penal code under the following articles:

\section{The Cameroon Penal Code and Domestic Violence}

The Penal Code in its article 278 states that no person is entitle to torture, physical and moral integrity, it also protects the right to life. It also states that serious injury caused by assault article 279 , Slight Injury article 281, Simple Injury article 280 are punishable except in cases of self-defense if provided by the law [34]. The Penal Code also prohibits force marriages and penalizes offenders with imprisonment and monetary fine art 356 of the 1981 law. It also punishes sexual harassment from six months to one year imprisonment and a fine of 100,000FRS, sexual assault from 5 - 10 years imprisonment [35].

According to Article 293 (1) of the Penal Code “(a) any person who reduces a person to or maintains a person in slavery, or (b) engages, even occasionally, in trafficking in human beings, shall be punished with imprisonment of ten to twenty years." Moreover, procuring is criminalized under article 294 which provides that "(1) Any person who causes, aids, or facilitates the prostitution of another individual or who shares, even occasionally, in the proceeds of the prostitution of another individual or receives subsidies from a person engaging in prostitution shall be punished with imprisonment of six months to five years and fine of 20.000 (US\$ 34.24) to 1.000 .000 francs. (2) Any person who lives with an individual engaging in prostitution and who cannot provide proof of sufficient resources to enable him to provide for his own needs shall be presumed to be receiving subsidies." Also prostitution is a punishable offence. Article 343 states, "(1) Any person of either sex who habitually engages, for compensation, in sexual acts with others, shall be punished with imprisonment for six months to five years and a fine of 20.000 to 500.000 francs (2) Any person who publicly recruits individuals of either sex through gestures, words, writings or any other means, for purposes of prostitution, or debauchery shall be punished with the same penalties." Additionally, Article 292 criminalizes forced labour. It states that "any person, who in order to satisfy his personal interests, imposes on another person any work or service obligation for which that person has not freely applied shall be punished with imprisonment of five to ten years and/or a fine of 10.000 to 500.000 francs." Cameroon has ratified the ILO Convention on the Abolition of Forced Labour and the UN Supplementary Convention on the Abolition of ?

The Cameroon Penal Code in its Section 293 (1) provides that:

\footnotetext{
${ }^{34}$ Penal Code Section 278 - 281

${ }^{35}$ Penal Code art 365 of the 1981 law
}

“(a) Any person who reduces a person to or maintains a person in slavery, or (b) engages, even occasionally, in trafficking in human beings, shall be punished with imprisonment of ten to twenty years." Moreover, securing is at the level criminalizing which provided for under article 294, states that

“(1) Any person who causes, aids, or facilitates the prostitution of another individual or who shares, even occasionally, in the proceeds of the prostitution of another individual or receives subsidies from a person engaging in prostitution shall be punished with imprisonment of six months to five years and fine of 20.000 fr to 1.000 .000 francs. (2) Any person who lives with an individual engaging in prostitution and who cannot provide proof of sufficient resources to enable him to provide for his own needs shall be presumed to be receiving subsidies."

The notion of prostitution has not been left out, it considered as a punishable offence under the Cameroon Penal Code. Article 343 states, “(1) Any person of either sex who habitually engages, for compensation, in sexual acts with others, shall be punished with imprisonment for six months to five years and a fine of 20.000francs to 500.000 francs (2) Any person who publicly recruits individuals of either sex through gestures, words, writings or any other means, for purposes of prostitution or debauchery shall be punished with the same penalties."

The situation of force labour has not been exempted under the Code. Article 292 states that "any person, who in order to satisfy his personal interests, imposes on another person any work or service obligation for which that person has not freely applied shall be punished with imprisonment of five to ten years and/or a fine of 10.000 francs to 500.000 francs." Cameroon has ratified the ILO Convention on the Abolition of Forced Labour and the UN Supplementary Convention on the Abolition of Slavery, the Slave Trade, and Institutions and Practices Similar to Slavery. Cameroon signed the UN Protocol to Prevent, Suppress and Punish Trafficking in Persons, especially women and children, adopted by resolution $\mathrm{A} / \mathrm{Res} / 55 / 25$, on 13 December 2000, but as of 09 October, 2003 had not ratified it. OMCT notes with concern that it is the prostitute who is punished rather than the client who goes free. As many prostitutes do not prostitute themselves of their free will, they are doubly victimised through these punishments.

\section{Examination of Some of the Offences of Violence on Women under the Cameroon Penal Code}

The Cameroon Penal code has given room for a series of offences that can be considered as domestic violence and affect the status and rights of women within a given society. The offences are grouped in a particular order because they have common elements as they are committed through the use of force and 
intentional on someone. Even though with its varieties spelled out in the Penal Code, their mental elements that provoked them may not be the same.

\section{Assault Occasioning Death}

This offence under the Cameroon criminal law system is considered as an involuntary homicide which is punishable under Section 278 of the Cameroon Penal Code which provides that:

"(1) whoever by force or interference unintentionally homicide another's death shall be punished with imprisonment for from six to twenty years.

(2) Where the force or interference is used in the course of any act of witchcraft, magic or divination, the punishment shall be imprisonment for life $\left[{ }^{36}\right]$."

Drawing inspiration from the above offence prescribed, one can say that for someone to claim that violence was used on him or her there must be the use of force or the aspect of interference. The perpetrator has committed a physical act as an act cannot be done on the victim by mere omission. The perpetrator must have used any part of his body or even an object to hit the spouse who is complaining of violence and such spouse must have felt the physical impact of the act. What we really need to note here is that the defendant's act must have really resulted in the death of the spouse. There must really be a dirent causal connection between the act of the husband and his spouse which is necessary to proof that the offence was committed. Let's take a critical example, there was a fight between a husband and a wife, the husband slapped the wife who suddenly collapses and was rushed to the hospital where the wife finally dies. The husband will be held criminally responsible for the wife's death even though his will was not to see his wife death.

Let's even say the act was not committed, because it is the role of the wife or spouse to prove that there was violence used on her by the husband. This can only be done with the presence of the intention which must be proven by the wife for it to amount to assault occasioning death. The observation of Lord Kenyon C.J in Fowler v. Padget $\left[{ }^{37}\right]$ where he believes that in common parlance, it is a principle that must be proven by the wife that there was violence or assault on her by not only talking about the use of force that lead to the death of the wife, but there must equally be the proof of the intention. The defendant needs not have intended the death of his spouse, so the presence of intention must be established. The provision of Section 74(2) of the Penal Code is clear when dealing with the aspect assault occasioning death by providing that:

\footnotetext{
${ }^{36}$ Section 278 of the Penal Code
}

${ }^{37}(1798) 7$ T.R. 509.
"Criminal responsibility shall lie on him who intentionally commits each of the ingredient acts or omission of the offence with the intention of causing the result which completes it $\left[{ }^{38}\right]$ ".

An observation under section 278 of the code is clear where it opines that the use of force or interference intentionally on the body of a spouse will amount to assault occasioning death, making the husband or defendant criminally liable and responsible for the act.

\section{Assault Occasioning Grievous Harm}

This is an offence that is handled by the Cameroon Penal Code in its Section 279 by establishing that:

"(1) whoever by force or interference unintentionally causes to another the injuries described in Section 277 of the this code shall be punished with the imprisonment for from five to ten years and in a fit case with fine of from five thousand to five hundred thousand.

(2) Where use is made of a weapon of any explosive, corrosive or toxic substance, of poison or any other act of witchcraft, magic or divination, the imprisonment shall be from six to fifteen years $\left[{ }^{39}\right]$ '”.

It can be recalled and examined in this offence that, for there to be assault occasioning grievous harm the presuppose use of force or interference on the body of a spouse with the intention of depriving the spouse of the use of her whole or part of any member organ or sense will be enough. For an action to be brought against the husband for assault, the wife must prove that the husband force or interference resulted to the wife permanent loss of the use of her whole or any part of any member organ or sense. When we talk about member organs here we are talking that the assault affected the wife organs like limb, leg or an arm; that is those organs of the wife's body that carries out special function like the kidney, pancreas, liver or even the lung. As to the senses here, we are talking about the five sense or faculties of sight, smell, hearing, taste or touch each other enabling the wife to respond to stimuli. There must be serious harm or hurt on the person which affects or interferes with woman health or comfort $\left[{ }^{40}\right]$.

\section{The Situation of Simple and Slight HARM caused on the Woman}

This is provided by Section 280 of the Penal Code which provides that:

\footnotetext{
${ }^{38}$ Section $74(2)$ of the Penal Code that deals with intention or the meas rea in a crime

${ }^{39}$ Section 279 of the Penal Code

${ }^{40}$ Curzon L.B, Criminal Law, $2^{\text {nd }}$ edition, M\& C Handbooks, pp.11
} 
"Whoever by use of force or interference causes intentionally or unintentionally to another any sickness or inability to work lasting more than thirty days shall be punished with imprisonment for from six months to five years or with fine of from five thousand to two hundred thousand francs, or with both such imprisonment and fine $\left[{ }^{41}\right]$."

For there to be proof of simple harm that is done on the wife, or spouse, the person must be able in establishing that there was a force or interference that was caused on her by the husband and this resulted to sickness or inability to work which lasted for more than thirty days. There was the lack of skill, carelessness, rashness or even disregard of regulations which causes the wife harm, sickness or incapacity to work.

Regarding that of slight harm, the offence is punishable under Section 281 by providing that:

"Whoever by force or interference causes intentionally or unintentionally to another any sickness or inability to work lasting for more than eight days and up to thirty days shall be punished with imprisonment for six days to two years or with fine of from five thousand to fifty thousand francs or with both such imprisonment and fine $\left[{ }^{42}\right] . "$

Looking at the two offences that is, simple and slight harm, they are similar as the defendant must have used force or interference on the spouse, which must have caused the spouse some sickness or inability to work for a number of days.

\section{Assault on Woman with Child}

This offence is handled in Section 338 of the Penal Code by providing that:

"Whoever by force used against a woman with child or against a child being born causes intentionally or unintentionally the death or permanent incapacity of the child shall be punished with imprisonment for from five to ten years and with a fine of from one hundred thousand to two million francs $\left[{ }^{43}\right]$ ".

From the position established above, one can say that there must be the presuppose use of physical violence against a pregnant woman or even against a child being born. The physical violence used must produce a result which can either cause the death of the spouse, or cause the spouse's child permanently incapacitated. Here we are talking about the health of the child. The child can be born strong and healthy, but because of the physical violence that was done on the mother when pregnant, she continues to suffer from

\footnotetext{
${ }^{41}$ Section 278 of the Penal Code

${ }^{42}$ Section 281 of the Penal Code

${ }^{43}$ Section 338 of the Penal Code
}

serious injuries resulting from the violent act of the husband. The husband cannot in any way deny this act as it is established that the physical force used by the husband produced the required result that the wife is suffering. The Cameroon Penal Code has offered great and special protection to a pregnant woman. Reference of this can be demonstrated by the provisions of Section 22(3) of the Code which states that:

\section{"No Woman with child may be executed until after her delivery". \\ This offence in question can lead or relates to} the offence of abortion of a woman with a child as it can be committed anytime from the conception of the baby to its delivery, when it becomes an independent human being distint from its mother. Section 337(2) of the Code reads:

"Whoever procures the abortion of a woman, nothwithsatnading her consent, shall be punished with imprisonment for from one to five years and with fine of from one hundred thousand to two million francs."

It is therefore possible that the use of force on a pregnant woman with a baby can lead to abortion as specified in the case of assault on a woman with a baby. All these offences illustrated are just to show how our criminal code handles issues of violence on a woman.

\section{Legal Contradictions in Matters Relating To Combatting Violence on Women Right}

There are lots of deficiencies constituting a hindrance affecting women rights in Cameroon making it difficult for this long time violence on women to be eradicated. There is a lot that has to be done in this old practice that has greatly affected the right and status of women making it practically and even impossibly difficult in combating this pandemic that that has constitute a threat and plague to the status occupied by women.

\section{The Infelicities and Inconsistencies Surrounding the Cameroon Penal Code}

There are lots of infelicities and discrimination when dealing or having a deep insight on the Cameroon Penal Code. When analysing issues related to violence on women, for the most part, the provisions are highly discriminatory making the duels to combat this dangerous pandemic difficult and worse than even the corona virus plaguing the world today. When having an understanding of some of the provisions of the code, one becomes confuse and questions whether the so called violence against women will ever be at the finishing lane. Glaring examples of these are those referred to adultery and abortion.

Talking about the concept of adultery, there are lots of controversies surrounding its understanding when dealing with women rights protection and status. 
Taking a good look at the provision of the penal Code in its Section 361 which provides that adultery is systematically if committed by a woman, but is only punishable when committed by a man if it is habitual or takes place in the matrimonial home $\left[{ }^{44}\right]$. Taking a good look at this provision it is against punishing the crime of adultery when committed by the husband as emphasis is laid as to the circumstances where the sexual intercourse of the husband will amount to adultery. The law has to use the word habitual elsewhere and in sex in the matrimonial home to amount to adultery when they really know that it will be difficult for the husband to admit adultery. It therefore means that if this husband commits adultery just once, it will not be a valid ground for the wife to bring an action against the husband for adultery. The law has provided an exception to what will amount to adultery, meaning that the women will continue suffering violence and threat from the husband whenever issues of adultery are brought up. The law also emphasizes that the adultery case must take place in the matrimonial home, what about sexual intercourse carried out by the spouse outside the matrimonial home? Does this mean it will not amount to adultery? $\left[{ }^{45}\right]$. The situation becomes even more complicated in establishing the crime of adultery in case of customary marriages. On what ground can a spouse bring an action against the husband under customary law. There is no evidence that the wife can institute since it will difficult to prove adultery and the fact that customary law allows or encourages the husband to marry as many wives as he deems fit. The man or husband will never feel guilty of adultery, unless the sexual intercourse occurred with another man's wife. There will always be that defence

\footnotetext{
${ }^{44}$ Section 361 of the Cameroon Penal Code

${ }^{45}$ The new Penal Code law of 2016 amending the provision of the 1967 law on adultery. Unlike the 1967 penal code which punished women simply for having sex with individuals other than their spouses, but equally punished men only if they had sex at home or habitually elsewhere with someone other than their wives, the new law punishes both men and women equally for sex with third party irrespective of where or how often. According to Section 361 of the new Code provide that:
}

- A woman who, being married, has sexual intercourse with a man other than her husband shall be punished with imprisonment for from two to six months or with a fine from 25000 frs to 100,000 frs

- A husband who has sexual intercourse with a woman other than his wife or wives shall be punished as provided by subsection 1 above. However, the burden of proof of the existence of polygamous union shall lie with the husband

- No prosecution may be commenced without the complaint of the wronged spouse.

Consent by wronged spouse to resume cohabitation shall put an end to the effects of conviction. by the husband that his extra marital relationship with a single woman is that he intends to marry her. It will concretely be difficult for the wife to bring an action for adultery against the husband for infidelity only in the case where the husband abandons her. The situation here is that, it is difficult to prove adultery using a direct witness, because practically it is difficult if not impossible to see the husband and another wife other than his wife on the matrimonial home or elsewhere committing adultery. The most part of the law depends on some circumstances presumed which basing only on those cannot amount to adultery.

The situation of abortion is also a serious problem preventing and slowing down the aspect of violence of men in the country. The Cameroon Penal Code is complicated and confusing when dealing with the offence of Abortion. As rightly stated under Section 337 of the code provides that:

1. "any woman procuring or consenting to her own abortion shall be punished with imprisonment from fifteen days to one year or with fine from five thousand to two hundred thousand francs or with both such imprisonment and fine.

2. Whoever procures the abortion of a woman notwithstanding her consent shall be punished with imprisonment from one hundred thousand to two million francs $\left[{ }^{46}\right]$ ".

It admits or permits abortion only when such abortion is criminalized and applicable if the mother's life is in danger or if pregnancy is the result of rape $\left[{ }^{47}\right]$. This is really confusing as we are aware that the issue of abortion is a complex one, placing only two circumstances in which abortion should not be punishable is questionable. There are so many reasons why some women will wants to commits abortion as it becomes a threat on their status and right. What about the situation where the woman is being abandoned by the person who impregnated her and he is at large?. The law has not considered the trauma psychological, emotional, and physical that this woman will go through before setting the ground for criminalising abortion. The law fails in understanding other circumstances that can affect the woman status or right in cases of abortion. The same law is talking about killing of a foetus to amount to abortion. The question one needs to pose here is determining at what period of the pregnancy it will amount to killing the foetus or baby. We are not in any way encouraging the concept of abortion of a woman, for we understand, abortion in its very origin is considered to be illegal as many

\footnotetext{
${ }^{46}$ Section 337(1) and (2) of the Penal Code

${ }^{47}$ Section 339 of the Penal Code that talks as to the exception of legalising abortion, or where abortion will be acceptable
} 
consider it a sin. Our worry here is for the legislation or law to be enacted taking cognizance of the fact that combating violence on a woman is a complex issue that needs to be defined unambiguously and carefully handled. There are some circumstances that the abortion might be caused as a result of the violence done on the spouse by the partner. There should be some modifications of Section 339 of the Penal Code to put more visibility on what is meant by severe danger to the mother's life particularly because the woman's health is not only physical. There can be the inclusion of important issues like the severe foetal malformations incompatible with life, incest and the reduction of administrative procedure attached to Section 339 of the Code.

\section{An Explanation of the Situation of Marital Rape}

Even the situation of rape is still a problem affecting combatting violence on women. The fact that marital rape or the so called spousal rape is the act of sexual intercourse with one's spouse without the spouse's consent, having sexual intercourse with the spouse without consent will amount to rape. This marital rape in all its implications is considered in most instances as domestic violence and sexual abuse. The common law rule of marital rape exemption is based on the cultural view that marriage makes a woman part of her husband's property, so that forced sexual intercourse is but a husband making use of his property. Taking a good base in the case of Achu v Achu inglis J in the Court of Appeal South West Region held that:

Customary law does not countenance the sharing of property especially

landed property, between husband and wife on divorce. The wife is still

regarded as part of the husband's property.

That conception is underscored by

the payment of dowry on marriage and on the refund of same on divorce.

Looking at the situation from the dictum above, once the marriage bride price has been paid by the husband; it therefore reduces the wife to a property. If the notion or concept that characterised a human being(wife) to become a property of another, then the notion of bringing an action for marital rape will be futile and unnecessary. The husband will not need as to customarily to be petitioned for rape when it concerns his property being the woman. Right from the day that the marriage is celebrated, the woman has given herself to the husband as a living sacrifice in which she must be available at all times the husband desires sexual intercourse, bringing an action for rape is useless. The Penal Code has talked of criminalizing rape in its Section 296 of the Code by punishing any person who by physical or moral violence forces a woman, including an adolescent to have sexual relations with him. We are not saying that rape is a good thing that should not be criminalised, but we are dealing with marital rape or rape in matrimony it is extremely difficult to bring an action against the husband for rape.

The situation becomes provocative as per the provision of Section 297 of the penal Code which prevents prosecution of rape when marriage has been freely consented to both parties, and the assaulted woman was over the age of puberty during the offence. We believe this is discriminatory and encourages the phenomenon of rape since the perpetrator knows that he can rape the woman and when he consents to get married to her, criminal proceeding against him will be discontinued. The issue here is that rape is rape, and when the fact or elements of rape are established, it should be punishable rather than giving instances where the rape will not amount to a criminal act. How then can we experience combatting when the law is encouraging or giving an opportunity to the rapist to be free from criminal responsibilities? How then can we we establish consent in this kind of marriage celebrated where we all know that the initial reasons for the celebration of the marriage stems from the rape incident?. The bone of contention here is that it will be difficult for the law or law enforcement officials to really have a proper or effective means of combatting when dealing with the offence of sexual violence on the woman. Neglecting certain fundamental aspects of the offence means that, combatting will becomes a total fiasco and disaster, thereby, rendering combatting or eradication difficult and impracticable. The Cameroon Penal Code being the watchdog in handling or criminalising issues of rape or violence against women is entangled with heaps of infelicities and lacunae's in which relying on it as a tool in combatting or handling issues of violence is questionable. The situation is not only with the penal code; even other areas of the laws have still become questionable in matters relating to domestic violence.

\section{The Complexities of the Civil Code in protecting Women's Rights and Status}

Controversially and inexplicably is an aspect that is defying and affecting our Civil Code from its French inception in matters relating to violence especially on women. It becomes confusing when some basic issues cannot be handled, and an overweighing pendulum is exercised on the woman's status and rights within a given society. A glaring example or illustration here can be examined in the domain of marriage as to parties. The code provides in its Article 52 that the minimum age for marriage is 15 years for the girls and 18 years for the boys. We all know as per the definition provided by the 1989 Convention of the Right of the Child in which Cameroon is not only a signatory but has ratified the said convention, provides in its Article 1 as follows: 
"any person who is below the age of $18 "[48]$

This becomes contradictory as per the Civil Code which has already fixed the marriage age of women. Even though the same code provides in its Article 49 that girls under 18 are not required to contract marriages, parental consent is sufficient. This is not a good ground at all in the country as it has really given birth to early or forceful marriage since the law gives the parents the opportunity in pushing their children to marriage before the prescribed day of the law. The code has to follow the provision as provided by Article 1 of the Convention of the Child which is considered as the ship anchored instrument of children rights in the country. The law was not foolish in establishing the minimum age for girls to get married at the age of 18. The law believes that children at that age are still considered as doli incalpax and lack certain faculties to understand the concept of marriage [49] or contract in which she is entering into. This situation of the law has really encouraged early marriage and made it difficult to combat or put an end to these barbaric practices in the country. We find the practices recurrent and practicable in our country like in the Northern part of the country where they believe it is common to give their girl children for marriage at the tender age. The problem here is evident in the fact that, though a long practiced tradition, our laws have also encouraged its practice, making it difficult for there to be its elimination and even suppression.

Even the fact that the law gives the husband the right to choose which matrimonial regimes to be applicable in the marriage agreement is a pertinent problem. According to the Cameroon Civil Code in its Article 70 which entails that if no choice is made as to the regime of marriage, and then the couple is married under common law which allows polygamy and community of marital property. So even the law accepts and encourages polygamy and at the same time, it vies to combat violence, what a paradox. The situation here is that even if the husband is for the monogamous regime, it doesn't stop the husband to be polygamous as we know the general adage that relates; "all Africans by nature are polygamous."

The husband is and will always be considered to be the head of the family [50]; he also has the sole right to determine the family domicile [51] and, in the

\footnotetext{
${ }^{48}$ Article 1 of the Convention on the Right of a Child

49 The situation of sound mind, sound memory and sound understanding is very instrumental for there to be a valid celebration of a marriage. The absent of these three elements in the celebration of a marriage will render the Marriage ceremony null and void.

${ }^{50}$ Article 213 of the Civil Code

${ }^{51}$ Ibid, Article 108 and 215
}

interest of the household and the children, may prevent his wife from taking employment [52]. This situation becomes rebellious and sarcastic, as we all know how it can ridicule the woman to nothing since the husband has absolute authority over their wife by depriving them from some privileges and advantages that she may derive. The man thinks he is the sole contributor or bread winner of the family and the wife is not in any best position to provide for the family depriving her of her own fundamental right to work which is established in many International Human Rights instruments and conventions that Cameroon has signed and ratified. The code in its entirety and realities gives much power to the husband who can violate her right at any time desired. The fact that women are also deprived of full use and enjoyment of property is a serious problem. [53] The husband has the right to administer communal marital property, thereby giving him the right to sell or mortgage the couple's property without his wife's consent. All these provisions are contradictory to our Cameroon Constitution especially in its preamble, wherein, it provides for equal rights to all irrespective of the status, sex, language, nationality in question. Both sexes have the right to enjoy the fundamental human rights, and the right to property is not an exception.

It is really shameful in our country that no specific laws have been enacted to prohibit violence against women or domestic violence. There are no laws prohibiting traditional harmful practices, and female genital mutilation (FGM) and the practice of breast ironing persist in parts of the North and the South-West Regions of the country.

Although the government report states that Cameroon's body of laws including the Constitution embodies the principle of equality between men and women, there is no legal definition of discrimination provided for by any law. The embodiment of the principle of equality in the preamble of the 1996 Constitution as amended in April 2008 is not sufficient to meet with the standards required by CEDAW, because discriminatory laws and practices still prevail. CEDAW is not yet incorporated into national laws. Article 45 of the Constitution states that duly approved

\footnotetext{
${ }^{52}$ Article 74 of the Cameroon Civil Status Registration Ordinance of 1981 provides that a husband may object to his wife's exercise of a trade different from him in the interest of their marriage or children

${ }^{53}$ Article 1421 and 1428 is a good example of the Code depriving the women from using the matrimonial property. It continues by saying that only the husband has the right to sell or mortgage the matrimonial property, the wife has no right as to the property of the matrimonial home as she herself is considered as a property, and how can a property own a property.
}

(c) 2021 | Published by Scholars Middle East Publishers, Dubai, United Arab Emirates 70 
or ratified treaties and International Agreements shall, following their promulgation, override national laws. This statement does not confer any rights or redress. Enforcement is therefore weak, since criminal sanctions have to be enacted into law before becoming applicable.

The problem sometimes is not at the level of identifying, discrepancies and complex nature of the laws that deals with domestic violence. The most difficult issue is at the level of those who are supposed to enforce and implement these laws put in place by the legal text. They hesitate and even sometimes are unwilling to ensure that the laws should be implemented. Most of them don't even see the necessity of intervening on issues related to the family as they believe the family is the most important unit or organ of the society that needs maximum protection and safety. They believe as well that, the disputes between the spouses can be resolved amicably rather than pushing the offender of the violence which in most cases is the husband. The issue of rape that is provided in our Penal Code which talks of punishing the rapist for an imprisonment term of five to ten years is a fallacy when dealing with issues related to marital rape. We know that matters relating to sexual intercourse encapsulates one of the duties attached to couples after the solemnity or celebration of the marriage $\left[{ }^{54}\right]$ and under no circumstances should this right be violated. A refusal to consummate the marriage can be considered a valid ground for the granting of a decree of divorce. The family being unique should be protected by everyone including the law enforcement officers. If those who are supposed to ensure that those who commit this crime on women, are the same people who are reluctant to solve or handle the problem, then there is a serious loophole that will automatically have an impact on combatting. The victims of the rape incident or other related violence will always be affected as the judicial actors become reticent to its combat. The laws are there which have provided room or circumstances in which those who commit those violence on women should be punishable, and it is thus, left for the judicial actors like the court, law officials and other enforcement officers to ensure the total application of the legal text and laws. However, every day we see cases of female violations being ignored and even avoided by these officers. This reluctant nature or aspect of domestic violence actions by the judicial actors constitute a discouraging aspect to most of the women who do not even see the need of reporting cases of violence to these actors as they know, nothing will be done on them, and thus unceasing violations. We believe the judicial actors should be capable of doing what they are vested by the law with,

\footnotetext{
${ }^{54}$ The incident of the right to consortium which parties owes to each other the right to sexual intercourse, and under no circumstances should any of the party deny or refuse the other of this right.
}

when issues of domestic violence are concerned. A criminal is a criminal whether it is the husband or wife. There is the need to impose them punishment in case of violence on the woman. When we consider a scenario where the actors of the judiciary are men, it further compounds implementation and combatting. Most men believe the women are property $\left[{ }^{55}\right]$ and so, how can property own a property? This stereotype reasoning drills the judicial officers to look at the women as inferior thereby finding it difficult to provide a solution to the existing problem faced the woman. The issue of adultery provided for in Section $361\left[{ }^{56}\right]$ of the Penal Code as Criminal is insignificant when it comes to the law enforcement official, they still have the conception that man by nature or from the origin is a polygamist, and committing adultery on the part of the man or husband is but normal which needs not to be over emphasized. The provision itself is problematic as it provides that for the men to be punished for the act of adultery, the act should have been committed in their homes or elsewhere habitually. This is falsified and opens an avenue for the supposed law enforcement officers to violate the law. The law says for adultery to be committed elsewhere it must be habitual $\left[{ }^{57}\right]$ as to the men, so when women report cases of adultery to the judicial actors, they are reluctant in the context of this provision and sometimes even ignore the law as they claimed that they cannot be proof of adultery since

\footnotetext{
${ }^{55}$ Customary law position of the law as to property rights which sees women as property and according to this law a property like woman cannot own a property. ${ }^{56}$ This section of the law talks about the aspect of adultery which should be punishable

${ }^{57}$ Thanks to the new law of 2016 amending the provision of the 1967 law on adultery. Unlike the 1967 penal code which punished women simply for having sex with individuals other than their spouses, but equally punished men only if they had sex at home or habitually elsewhere with someone other than their wives, the new law punishes both men and women equally for sex with third party irrespective of where or how often. According to Section 361 of the new Code provide that:
}

- A woman who, being married, has sexual intercourse with a man other than her husband shall be punished with imprisonment for from two to six months or with a fine from 25000 frs to 100,000 frs

- A husband who has sexual intercourse with a woman other than his wife or wives shall be punished as provided by subsection 1 above. However, the burden of proof of the existence of polygamous union shall lie with the husband

- No prosecution may be commenced without the complaint of the wronged spouse.

- Consent by wronged spouse to resume cohabitation shall put an end to the effects of conviction. 
having direct evidence as to adultery is always difficult $\left[{ }^{58}\right]$.

\section{The Lack of Litigation}

The problem of litigation or issues of lawsuits are absent or even lacking when dealing with matters related to domestic violence or violence on women. How many women who are victims of domestic violence will be confident in bringing actions against their husbands sometimes the women who file complains turn to withdraw due to further violence and some even refuse that an action should not be filed in court. Limited filing of cases and withdrawals might result from the fear to be mocked by other women in the family or other family members or friends. Sometimes pursuing a case is too expensive and the process is too long. This tends to discourage them. Victims sometimes show the centre to be weak and that it can only recommend, does not take effective decision and as a means of enriching themselves. For example overheard a conversation between staff of a withdrawn case by the complainer, that is, a victim files a complaint and later withdraws it due to threat. Since the victims are afraid of been mocked, they prefer to keep quiet thereby leading to an increase in domestic violence since the perpetrator knows the partner cannot file a complaint. How will the law even entertain or even show possible actions in handling violence against women cases, when there no existence of lawsuits by the victims of the violence. They women are complaining everyday about the abuse done on them or the violation of their rights as a woman by their supposed husband who exerts assault on them, but they lack the courage to prosecute their husband. They believe that marriage is a sacred institution which needs to be protected at all cost, so bringing or taking an action against their husbands will constitute a breach of confidence of upholding this prestigious institution. They prefer to bear and die in silence even when they are aware that they are victims of violence from their husbands. Some even stay and refuse to report abuse cases for the sake of their children as they think it is their responsibility to protect their children against public mockery and insults. There is also the facet concerning women in the rural areas who have little or no knowledge about the existence of the centre and other NGOs that they can complain to. It is very

\footnotetext{
${ }^{58}$ Family law Lecture Notes, Simon Tabe Tabe where it was established that proving adultery on direct eye witness is difficult, as to the provision of Section 1(2) (A) of the Matrimonial Causes Act 1973, since it is difficult to proof adultery by mere eye witness, it has provided for circumstances that the petitioner can use and establish and it will still amount to adultery. Situations such as undue familiarities, evidence of spouses, marital confidence, veneral diseases, blood test and a host of others will amount to adultery.
}

difficult for the centre to go into the remote areas to educate the population there about human rights and women's rights in particular. Women who have knowledge about the centre are afraid to lay their complaints because of the fear of violating their traditions. This fear causes them to remain quiet and live in pains. This problem of unawareness is due to the fact that since many communities are inaccessible and no service vans are available to go to such areas, makes the people to remain ignorant of the fact that domestic violence is a crime against humanity. They continue to live in violence and do not see anything wrong in it since they have no ideal of it being considered as a crime under Cameroonian laws. Combatting violence or domestic violence on women is a difficult and pragmatic unreality that will be a nightmare on the part of the law to handle as most of the victims of the violence are women who in most cases find it difficult in reporting cases of violence. Most traditions in Cameroon do not consider rape between husband and wife. This is because they believe that the husband has the right to have intercourse with the wife as he wishes. The wife is seen as a property that does not belong to the husband alone but to the whole family. With all these obscure traditions, the Centre finds it difficult to change the mentality of the people. Women who are victims of domestic violence cannot even file a complaint or return to their father's houses. Reasons being that tradition forbids return of bride price and it is seen as a taboo. Some of these women are even afraid of being punished by the custodian of their traditions. All these make things difficult for us to experience complete combatting or suppression of the crimes on them. Those that even disclose it are still afraid. The fear in them makes them to request non-disclosure to anyone. We believe the law will not force these women to bringing actions against their husbands' in cases of abuse or violence. The women or the supposed victims are those suffering from these inconsistencies or violence on their right, but how many of them have that courage to bring actions against their husbands? They believe that they owe that obligation to be submissive and respect their husband as they consider them as the sole provider of the family, bringing or reporting cases of violence against them will make them to be deprived of the privileges that they acquire. It is thus the fundamental human right of the women to be treated humanely as the law gives and maintains their position and status that they occupy, they should be bold enough to bring or report cases when faced with abuse or violations of their rights and status by their husbands. The law officials are there to help them combat this crime by punishing those who violate or abuse their rights and status. But it will difficult in handling this issue of combatting violence if cases of violence or abuses are not reported. It was not by chance that the Universal Declaration of Human Right 1948 in its article 2 talks about the responsibility of everyone to respect the dignity of all regardless of their genetic 
characteristics $\left[{ }^{59}\right]$. Cameroon has recognised this right in its preamble by ensuring that fundamental human rights are respected $\left[{ }^{60}\right]$ in which those pertaining to women are not an exception $\left[{ }^{61}\right]$.

\section{CONCLUSION}

Human rights nowadays is highly promoted and protected by international customs, treaties as well as national laws. Fundamental human rights encompass all humanity and the rights are attached to man as man becomes humanity. Women are not exempted from such rights and should be treated fairly by their partners, relatives and community. There is the need to protect women's rights in spite of the fact that they still face violence every day. This work affirms that women rights are promulgated and guaranteed by international instruments such as the Convention on the Elimination of all Forms of Discrimination against Women, the Maputo Protocol, the Universal Declaration of Human Rights, and Declaration on the Elimination of Discriminations against Women. These rights are also indicated in the constitution, penal code, and criminal procedure code of Cameroon.

Though the State has done so much in eradicating domestic violence against women, some malpractices such as breast ironing, FGM, sexual harassment, physical violence and more are still in existence. In the course of carrying out their mission of protecting and promoting women's rights, they face a lot of roadblocks ranging from inadequate funds, personnel, unawareness, lack of service cars to carry out their activities and many more. Even though so many laws have been put in place to protect human rights and women's rights in particular, women are still victims of domestic violence. This accentuates the threat on the socio-economic situation of the country since the respect of human rights and that of women is indispensable. Therefore, we suggest that the following recommendations should be taken into consideration and acted upon so that a better human rights culture can be implemented.

\section{REFERENCES}

1. Grdinic, E. (1999). Application of the Elements of Torture and Other Forms of Ill-Treatment, as Defined by the European Court and Commission of Human Rights, to the Incidents of Domestic Violence. Hastings Int'l \& Comp. L. Rev., 23, 217.

2. Rebecca P. Sewall. (1996). Women, Law \& Development International, State Responses To

\footnotetext{
${ }^{59}$ United Nations General Assembly Resolution 217 A

${ }^{60}$ Section 65 of the 1996 Constitution provide that the preamble is considered as an integral part of the constitution.

${ }^{61}$ Section 1 of the Cameroon Penal Code provides that everyone is equal before the law
}

Domestic Violence: Current Status And Needed Improvements,

3. Albert, R. Roberts. (2002). Handbook of Domestic Violence Intervention Strategies: Policies, Programs, And Legal Remedies 102,

4. Rennison, C. M. (2003). Intimate partner violence, 1993-2001. Washington, DC: US Department of Justice, Office of Justice Programs, Bureau of Justice Statistics. Rennison, C. M. (2003). Intimate partner violence, 1993-2001. Washington, DC: US Department of Justice, Office of Justice Programs, Bureau of Justice Statistics.

5. Bonita, M. (2013). A Theory of Domestic Violence in International Law, JSD Thesis, Yale Law School

6. Isabel, M. (1994). Reframing "Domestic Violence": Terrorism in the Home, in The Public Nature of Private Violence The Discovery of Domestic ABUSE, 11, 26-7 (Martha A. Fineman \& Roxanne Mykitiuk eds., 1994)

7. Velzeboer; Mary Ellsberg; Carmen Clavel arcas; claudia garciá-moreno, Violence Against Women: The Health Sector Responds 4 (Pan American Health Organization \& Path

8. Subedi. (1997). Protection of Women against Domestic Violence: The Response of International Law, E.H.R.L.R. 6 587-606, 592-3.

9. Fineman, M., \& Mykitiuk, R. (Eds.). (1994). The public nature of private violence: The discovery of domestic abuse. Psychology Press.

10. Fraser, A. S. (1999). Becoming human: The origins and developments of women's human rights. Hum. Rts. Q., 21, 853.

11. Bond, J., \& Phillips, R. (2001). Violence against women as a human rights violation: International institutional responses. Sourcebook on violence against women, 481-500.

12. Coomaraswamy, R. (2000). Combating domestic violence: Obligations of the State. Domestic violence against women and girls.

13. Jacobson, N. S., \& Gottman, J. M. (1998). When men batter women: New insights into ending abusive relationships. Simon and Schuster.

14. Fals-Stewart, W., \& Kennedy, C. (2005). Addressing intimate partner violence in substanceabuse treatment. Journal of substance abuse treatment, 29(1), 5-17.

15. Gondolf, E. W. (1995). Alcohol abuse, wife assault, and power needs. Social Service Review, 69(2), 274-284.

16. Anderson, E. (1990). Streetwise: Race, Class, and Change in an Urban Community. Chicago: Univ.

17. Benson, M., \& Fox, G. L. (2004). When violence hits home: How economics and neighborhood play a role, research in brief. NCJ, 205004.

18. Miller, J. (2008). Getting played: African American girls, urban inequality, and gendered violence (Vol. 9). NYU Press.

19. Raghavan, C., Mennerich, A., Sexton, E., \& James, S. E. (2006). Community violence and its direct, 
indirect, and mediating effects on intimate partner violence. Violence Against Women, 12(12), 11321149 .

20. El, Barrio. (1999). In search of respect: Selling crack in New York: Cambridge University Press; DeKeseredy, W.S., Alvi, S.,

21. Renzetti, C. M. (2009). Economic stress and domestic violence.

22. Bourgois, P. (1999). In search of respect: Selling crack in El Barrio, New York: Cambridge University Press.

23. DeKeseredy, W. S., Schwartz, M. D., Alvi, S., \& Tomaszewski, A. E. (2003). Under siege: Poverty and crime in a public housing community. Lexington Books.

24. Sanday, P.R. (2007). Fraternity gang rape: Sex, brotherhood, and privilege on campus (2 nd ed.). New York: New York University Press.

25. Bell, K. M., \& Orcutt, H. K. (2009). Posttraumatic stress disorder and male-perpetrated intimate partner violence. JAmA, 302(5), 562-564.

26. Teplin, L. A., McClelland, G. M., Abram, K. M., \& Weiner, D. A. (2005). Crime victimization in adults with severe mental illness: comparison with the National Crime Victimization Survey. Archives of general psychiatry, 62(8), 911-921.

27. Trevillion, K., Oram, S., Feder, G., \& Howard, L. M. (2012). Experiences of domestic violence and mental disorders: a systematic review and metaanalysis. PloS one, 7(12), e51740.

28. Sharps, P. W., Campbell, J., Campbell, D., Gary, F., \& Webster, D. (2001). The role of alcohol use in intimate partner femicide. American Journal on Addictions, 10(2), 122-135.

29. Burt, M. R., Aron, L. Y., \& Lee, E. (2001). Helping America's homeless: Emergency shelter or affordable housing?. The Urban Insitute.

30. Wickeri, E., \& Kalhan, A. (2010). Land rights issues in international human rights law. Malaysian journal on Human rights, 4(10).

31. Nicholas, M. (2007).' Breast Ironing in Cameroon: an overview for fair fund', Jeunesse Horizon, August, 2\$3

32. Nussbaum, MacDougal, Lasswell., \& Chen, Okin, U.N. Reports White ribbon, 'Understanding Domestic Violence-Types of Abuse, Physical Abuse',

33. Curzon, L.B. Criminal Law, $2^{\text {nd }}$ edition, $M \& C$ Handbooks

34. Alio, Amina, P. (2011). "Association between intimate partner violence and induced abortion in Cameroon," 112 International Journal of Gynecology \& Obstetrics 2 (Feb. 2011).
35. Anyangwe, C. (1987). The Cameroonian Judicial System, Yaounde : CEPER

36. Nisha, G. (2012). The Global Spread of Domestic Violence Legislation: Causes and Effects.

37. Bawe, R. N. (2011). Breast Ironing: A Harmful Traditional Practice in Cameroon

38. Fareda, B. (2005). Women, Law and Human Rights, Oxford Portland Oregon, Hart Publishing

39. Roberta, A., \& Noelle, Q. (2008). International Humanitarian Law and Human Rights Law: Towards a New Merger in International Law, Martinus Nijhoff Publishers

40. Rhona, K.M. Smith. (2014). Textbook on International Human Rights, Oxford University Press, $6^{\text {th }}$ Edition

41. Advocates for Human Rights, Cameroon. (2014). Committee on the Elimination of Discrimination Against Women 57th Session, 24 January 2014

42. USDOS. (2018). Trafficking in Persons Report, 28 June 2018,

43. UN Economic Commission for Africa African Centre for Gender and Social Development (ACGSD). (2010). Violence against Women in Africa: A Situational Analysis, 28

44. Advocates for Human Rights, Cameroon. (2014). Committee on the Elimination of Discrimination Against Women 57th Session, 24 January 2014,

45. OECD Social Institutions and Gender Index, Country Profile: Cameroon,

46. UN OCHA, Cameroon. (2019). North-West and South-West Situation Report No. 3, 31 January 2019

47. NGO Report On the implementation of the ICCPR (Replies to the List of Issues, available at CCPR/C/CMR/Q4)

48. Country Reports on Human Rights Practices for 2012: Cameroon, U.S. Department of State (2012),

49. Beijing +15 , The Reality of Cameroon and the Unfinished Business, Assessing the Implementation of the Beijing Platform of Action in Cameroon, July 2010

50. CAFEJ 'The convention on Elimination of all forms of Discrimination Against Women from AZ'

51. OECD. (2014). Social Institutions \& Gender Index. 2014 Synthesis Report

52. UNICEF. (2005). Early Marriage: A Harmful Traditional Practice. New York: United Nations

53. UNFPA. (2004). Child Marriage Advocacy Programme: Fact Sheet on Child Marriage and Early Union. 